\title{
The Role of the Immune System in the Pathogenesis of Diabetic Nephropathy
}

\author{
Maria-Gabriela Velez and Vivek Bhalla*
}

Division of Nephrology, Department of Medicine, Stanford University School of Medicine, Stanford, CA, USA

\begin{abstract}
Diabetic nephropathy (DN) is the most common cause of end-stage renal disease (ESRD) in adults. Despite our current understanding of the disease, we cannot accurately predict which patients with diabetes will develop nephropathy, and we cannot halt the progression to ESRD. Research on the role of the immune system in DN may shed light on novel biomarkers and therapies for this severe complication of diabetes mellitus. In this review we examine the current knowledge of the role of immune system in the development and progression of diabetic nephropathy, speculate on the potential role of B lymphocytes, and highlight implications for prognosis and therapy.
\end{abstract}

Keywords: Inflammation; Macrophages; T Lymphocytes; Complement; Immune complex; B Cells; Autoantibodies

\section{Introduction}

Diabetic Nephropathy (DN) is the most common cause of EndStage Renal Disease (ESRD) in adults, and nearly $50 \%$ of chronic kidney disease $(\mathrm{CKD})$ and ESRD cases in the United States are due to diabetes mellitus [1]. Among persons with diabetes mellitus the prevalence of nephropathy ranges from 15 to $40 \%$ depending on the type of diabetes mellitus (type 1 or type 2 ) and the severity of disease (albuminuria, CKD, ESRD, etc.) [2,3]. While improvements in glycemic control and the use of inhibitors of the Renin-Angiotensin-Aldosterone System (RAAS) have shown promise in clinical trials, the growth in incidence and/or severity of CKD in diabetes has not decreased over the past two decades [2]. Moreover, the increase in the prevalence of diabetes [2] and the high cardiovascular risk associated with CKD and ESRD $[4,5]$ substantiates that to care for these patients, we will utilize a disproportionate amount of health care dollars in the coming decades.

Despite great strides in our understanding of the pathophysiology of diabetic nephropathy, several elements of the disease are not well understood. While only a minority of patients with diabetes will develop nephropathy, predictive risk factors are not fully elucidated. Once overt diabetic nephropathy is present (defined as macroalbuminuria, $>300 \mathrm{mg}$ urine albumin to gram of creatinine, and $>3 \mathrm{ml}$ decrease in estimated GFR/min/year [6,7], the inexorable progression to ESRD can be slowed but not reversed [8] . Therefore, we need to better understand the early pathophysiologic mechanisms of diabetic nephropathy in order to develop both better biomarkers and intervention strategies.

Diabetic nephropathy is initially characterized by hyperfiltration, followed by pathologic changes in the glomerulus including podocyte apoptosis and Extra Cellular Matrix (ECM) accumulation in the basement membranes and mesangium $[9,10]$ which then cause microalbuminuria. Eventually, these patients develop glomerulosclerosis and tubulo-interstitial fibrosis which is associated with decreased glomerular filtration, and finally ESRD [11,12]. Metabolic and hemodynamic factors were thought to be the main causes of glomerular and tubular injury in diabetic nephropathy. However, recent data support the notion that the mechanisms of diabetic nephropathy also involve the immune system. Several elements of the immune system including cytokines and resident chemokines, macrophage recruitment, $\mathrm{T}$ lymphocytes, and immune complex deposition have been implicated in other glomerular diseases but have now been associated with diabetic nephropathy. In this review we examine the role of the immune system in the development and progression of diabetic nephropathy, speculate on the potential role of B lymphocytes, and highlight implications for prognosis and therapy.

\section{Cytokines/Chemokines in Diabetic Nephropathy}

Patients with diabetes have increased serum expression of key inflammatory cytokines [13]. One hypothesis is that hyperglycemia and the associated oxidative stress' damages endothelial cells which in turn release cytokines and chemokines. One study has shown that hyperglycemia-induced glycation end-products stimulate secretion of monocyte chemoattractant protein from human mesangial cells in vitro [14]. Furthermore, production of aberrant cytokines and chemokines (tumor necrosis factor- $\alpha$ [TNF- $\alpha]$, interleukin-1, interferon- $\gamma$, and transforming growth factor $\beta$ ) correlates with the degree of proteinuria in a small cohort of patients with overt diabetic nephropathy [15]. Similarly, the kidneys in streptozotocin-induced diabetic rat models also express elevated levels of inflammatory cytokines [16]. Many of these cytokines cause podocyte apoptosis and matrix accumulation albeit in tissue culture models [17], which warrant further study in vivo.

Thus, cytokine signalling in the diabetic kidney, reviewed elsewhere, [18] may play an important role in the pathogenesis of early diabetic nephropathy, and perhaps interventions to attenuate these pathways could be an avenue for therapeutics. Cytokines and chemokines have also been implicated in the recruitment of macrophages and $\mathrm{T}$ cells to the diabetic kidney [19].

\section{Role of Macrophages in Diabetic Nephropathy}

Local macrophage accumulation may herald the development of common diabetic complications such as atherosclerosis, nephropathy, neuropathy, and retinopathy. Glomerular infiltration of macrophages in diabetic kidneys has been fairly well established by examining diabetic kidney biopsies from mice and humans [16,21]. In kidney biopsies from patients with type 2 diabetes mellitus, macrophage

*Corresponding author: Vivek Bhalla, Division of Nephrology, 780 Welch Road, Suite 106, Stanford University, Palo Alto, CA 94304, USA, Fax: 650-721-1443 E-mail: vbhalla@stanford.edu

Received February 14, 2012; Accepted May 19, 2012; Published May 21, 2012

Citation: Velez MG, Bhalla V (2012) The Role of the Immune System in the Pathogenesis of Diabetic Nephropathy. J Nephrol Therapeutic S2. doi:10.4172/2161-0959.S2-007

Copyright: @ 2012 Velez MG, et al. This is an open-access article distributed under the terms of the Creative Commons Attribution License, which permits unrestricted use, distribution, and reproduction in any medium, provided the original author and source are credited. 
accumulation within the interstitium is proportional to the level of proteinuria [22]. Progressive glomerular injury and fibrosis associated with increased macrophage accumulation has also been observed in different rodent models of diabetic nephropathy, and macrophages account for almost all kidney leukocyte accumulation in the glomerulus by immunofluorescence [23-25]. Adoptive transfer of alternate macrophages (M2 cells), programmed to suppress macrophage activity, to a streptozotocin-induced mouse model of type 1 diabetes results in decreased accumulation of macrophages within the kidney [26] providing in vivo evidence of cellular recruitment in diabetic nephropathy.

Modulation of macrophage recruitment attenuates diabetic nephropathy in mouse models. In C57BL/6 mice, streptozotocininduced hyperglycemia increases kidney expression of Monocyte Chemoattractant Protein-1 (MCP-1), a potent macrophage chemokine [27] and MCP-1 deficiency results in decreased accumulation of macrophages in the kidney with subsequent protection from both histological damage and renal dysfunction [27,28]. Intracellular Adhesion Molecule (ICAM-1) also recruits macrophages, and an ICAM-1 deficient $\mathrm{db} / \mathrm{db}$ mouse model of type 2 diabetes showed decreased leukocyte infiltration, reduced glomerular hypertrophy, decreased albuminuria, and decreased tubulo-interstitial fibrosis [29]. Pharmacological blockade of the C-C Chemokine Receptor 2 (CCR2) involved in the mobilization of macrophages out of the bone marrow' results in a similar phenotype of decreased glomerular cellular infiltration' and decreased albuminuria [30]. These data support the hypothesis that macrophage recruitment and activation contribute to the structural and functional changes characteristic of diabetic nephropathy. The mechanisms for how recruited, activated macrophages induce glomerular damage resulting' in podocyte apoptosis, basement membrane thickening' and mesangial cell expansion remain an area of ongoing research. Based on current data, activated macrophages release reactive oxygen species and inflammatory cytokines which beget further tissue injury.

\section{Role of T Lymphocytes in Diabetic Nephropathy}

The recruitment of activated T-lymphocytes to the diabetic kidney may also contribute to development of proteinuria. Bending and colleagues observed in the renal parenchyma that the absolute number and percent of activated T-lymphocytes in the renal parenchyma was significantly higher in insulin dependent patients with diabetes with proteinuria than without proteinuria $[16,31] . \mathrm{CD} 3+\mathrm{T}$ cells have also been found in the interstitium of mice with streptozotocin induced diabetes and proteinuria [32].T cells infiltrating the diabetic kidney produce inflammatory cytokines, such as TNF- $\alpha$, interleukin- 6 and interferon $-\gamma$. These $\mathrm{T}$ cells likely contribute to local inflammation and tissue damage $[32,33]$. Using $\mathrm{db} / \mathrm{db}$ mice Eller et al. have recently shown that suppressing the activity of $\mathrm{T}$ cells prevents development of diabetic nephropathy. Adoptive transfer of regulatory T cells (Tregs), an immunosuppressive population of cells that dampen and counteract' active inflammatory $\mathrm{T}$ cells, decreased glomerular diameter' and albuminuria. Conversely, depletion of Tregs resulted in progression of diabetic nephropathy with increased glomerular diameter and increased albuminuria [34].

Lim et al. [35] examined the role of lymphocytes in diabetic nephropathy directly by inducing diabetic kidney injury using streptozotocin-induced diabetes in lymphocyte deficient $\mathrm{Rag}^{-1}$ mice, which lack mature $\mathrm{T}$ and $\mathrm{B}$ lymphocytes. Twenty weeks after onset of diabetes wild-type and $\mathrm{Rag}^{-/}$mice both develop equivalent hyperglycemia, but only the wild-type mice showed evidence of kidney infiltration with CD4 and CD8 lymphocytes as well as glomerular immunoglobulin (Ig) deposition. The $\mathrm{Rag}^{-1-}$ mice show similar macrophage accrual, histologic damage, matrix expansion, and loss of renal function but are protected from increased albuminuria measured at 8 to 20 weeks following onset of diabetic phenotype. The $\mathrm{Rag}^{-/-}$mice are protected from podocyte loss, and glomerular macrophage activation' which may result in the protection from albuminuria. However, the $\mathrm{Rag}^{-1-}$ mice were on a C57BL/6 background and studies in other mouse strains that are more robust models of diabetic nephropathy are still required [36,37]. A recent study by Awad using $\mathrm{Rag}^{-/}$mice on C57BL/ 6 background found no protection from proteinuria at 6 weeks following streptozotocin induction [38] demonstrating the need for more consistent and robust mouse models. Decreased Tcell infiltration and activation may represent another immune-mediated pathway for treatment of diabetic nephropathy.

\section{Complement Fixation and Immune Complex Deposition in Diabetic Nephropathy}

There are emerging data that activation of the complement cascade may contribute to human diabetic nephropathy $[39,40]$. Hyperglycemia-induced intracellular generation of reactive oxygen species activates complement [39]. Another route for complement activation is immune complex deposition. Ainsworth and colleagues examined 16 kidney biopsies from type 1 and type 2 diabetic patients with diabetic nephropathy, and were among the first to observe complement and immune complex deposition in both the glomerular basement membrane and mesangium [20]. Based on the immunofluorescence findings the authors concluded that the morphologic alterations observed in diabetic glomerulopathy might be mediated by immune mechanisms [20].

Circulating immune complex levels have also been associated with the development of albuminuria and proliferative retinopathy in patients with diabetes, suggesting immunoglobulin (Ig) deposition can promote tissue injury [41-43]. In both adults and children with diabetes significantly higher levels of circulating IgG immune complexes correlate with microalbuminuria, suggesting that elevated levels of circulating immune complexes are associated with the development of early diabetic nephropathy [42]. Circulating immune complexes have also been detected in several rodent models of diabetes at higher titers than controls and are associated with increased glomerular deposition $[40,44]$. In these models glomerular deposition of Ig and C3 has been correlated with renal injury [45-47]. Several pathogenic mechanisms of immune complex deposition in diabetic renal injury have been proposed. Glomerular and tubular basement membrane thickening may involve an antigen-antibody reaction that stimulates resident cells to proliferate [42]. Moreover, certain immune complexes stimulate mesangial expansion by inducing collagen production [48]. Immune complexes may also promote glomerular macrophage accrual. For example, in diabetic $\mathrm{db} / \mathrm{db}$ mice increased accumulation of macrophages in the glomeruli correlates with an increased glomerular deposition of IgG [23]. The immune complexactivated complement cascade was directly tested in a study using human antibodies to oxidized low-density lipoproteins (Ox-LDL) collected from sera of patients with type 1 diabetes. Human anti-OxLDL antibodies incubated with complement fragments in vitro form immune complexes and trigger activation of the classical complement pathway. Moreover, Ox-LDL immune complexes induce inflammatory cytokine release from macrophages in vitro [49]. 
Fujita et al. [47] used a known inhibitor of the complement cascade in a diabetic rat model to test whether the complement system plays a role in the progression of diabetic glomerulosclerosis. The complement inhibitor significantly reduced mesangial expansion and proteinuria in these rats, and this was associated with a decrease in glomerular deposition of Ig and C3. These data indicate that the complement cascade is activated by injured glomeruli, and this activation exacerbates diabetic glomerulosclerosis. Moreover, they provide a therapeutic rationale for complement inhibition in patients with diabetic nephropathy.

\section{Proposed role of B lymphocytes and AutoAntibodies in Diabetic Nephropathy}

There are limited data regarding the role that B cells might play in the pathogenesis of diabetic nephropathy. B cells appear to infiltrate the kidney of patients with type 2 diabetes, but it remains unclear if these cells directly cause tissue injury [32]. Evidence of glomerular immune complex deposition and increased autoantibodies titers in sera of diabetic patients and mouse models of diabetic nephropathy implicate $\mathrm{B}$ cells in the mechanism of diabetic nephropathy. Development of autoantibodies to kidney antigens may contribute to the development of diabetic kidney injury, because patients with diabetes have increased levels of serum immunoglobulins including antibodies against selfantigens modified by glycoxidation or lipoxidation [41,42,50-53]. These circulating autoantibodies can form immune complexes that deposit in glomeruli and promote activation of complement or macrophages.

Autoantibodies have been documented in diabetes, including antiinsulin autoantibodies [54]. Anti-single-stranded DNA antibodies are detected at higher titers in sera of patients with diabetic complications in comparison to controls, and these autoantibodies appear to be closely associated with the presence of vascular complications such as nephropathy [55]. Ox-LDL is immunogenic, and immune complexes formed by the corresponding autoantibodies are proatherogenic and pro-inflammatory [56]. Atchley et al. determined that the concentration of Ox-LDL immune complexes is increased in patients with macroalbuminuria [41]. Another study measuring $\operatorname{IgG}$ Ox-LDL antibodies in the sera of 34 patients with type 1 diabetes determined that the concentration of these antibodies was higher in the nephropathy cases, as defined by higher albumin excretion rate and lower glomerular filtration rate compared to controls [57].

Using the Non-Obese Diabetic (NOD) mouse model, a model of autoimmune type 1 diabetes, Xiao et al. examined the involvement of cellular and humoral immunity at various time points in the progression of diabetic nephropathy [46]. They found that glomeruli of diabetic NOD mice were infiltrated with T cells, B cells, and dendritic cells. Moreover, they found IgG deposits along with complement C3 in the glomeruli of diabetic NOD mice. Interestingly the serum from these diabetic mice contained autoantibodies directed towards components of the glomeruli, which were not present in serum of the control mice. These immune changes in the kidney were associated with increased kidney weight and urinary albumin excretion. These autoantibodies only develop after the mice become diabetic and appear to be directed towards renal endothelial cells and the glomerular basement membrane. These studies demonstrate the relationship between B lymphocytederived autoantibodies and diabetic kidney injury providing a rationale to target B lymphocytes to halt immune complex deposition. Studies have shown that immunization of hypercholesterolemic mice with given peptides inhibits the development of atherosclerosis [58]. Hence,

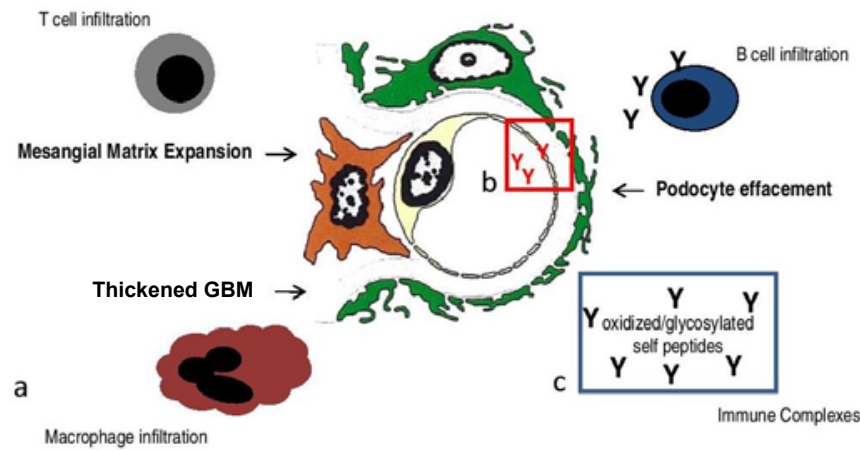

Figure 1: Lymphocyte

and antibody-mediated tissue damage contributes to the development of diabetic nephropathy (DN). The inflammatory environment generated by increased production of cytokines and chemokines in diabetes results in the recruitment of macrophages and $T$ lymphocytes to the diabetic kidney (a) which further promotes the inflammatory process. Oxidation and glycosylation of native peptides ensues as a result of oxidative stress and hyperglycemia associated with diabetes. These modified self peptides serve as novel antigens leading to production of B-cell derived autoantibodies that deposit in the glomerular basement membrane (GBM) (b) and generate circulating immune complexes (c). These autoantibodies may further promote inflammation and structural damage by activating complement and recruiting macrophages. Modified with permission from Cheung et al. [61].

it may also be possible to develop vaccines to dampen diabetic kidney injury. Importantly, the presence of autoantibodies may also provide valuable non-invasive serum biomarkers for the early detection of disease.

\section{Future Directions}

Manipulating the immune system and decreasing inflammation associated with diabetic kidney injury could provide therapeutic targets. The use of immunosuppressants and neutralizing antibodies has been shown to reduce leukocyte accumulation in diabetic kidneys and to decreased injury $[25,59,60]$. In a streptozotocin-induced model of diabetes, treatment with TNF- $\alpha$ inhibitors, infliximab and FR167653, decreased albumin excretion in diabetic rats [60]. In another streptozotocin rat model, daily treatment with antiproliferative mycophenolate mofetil (MMF) by gavage resulted in decreased glomerular macrophage infiltration, glomerulosclerosis, and albuminuria [59,61].

There is growing evidence that macrophages and T cells, recruited by locally-derived chemokines play a role in diabetic nephropathy by generating further cytokines resulting in progressive injury and fibrosis. Immunoglobulin deposition results in tissue damage and complement activation leading to further progression of inflammation and recruitment of more macrophages and $\mathrm{T}$ cells. The role for $\mathrm{B}$ cells in diabetic kidney injury appears to be via the generation of autoantibodies and immune complexes (Figure 1). Autoantibodies to oxidized and glycosylated proteins (whose unmodified form would be recognized as self and therefore not produce antibodies) could serve as non-invasive biomarkers for identifying patients with diabetic nephropathy before the onset of clinical signs and symptoms.

\section{References}

1. Collins AJ, Foley RN, Chavers B, Gilbertson D, Herzog C, et al. (2012) 'United States Renal Data System 2011 Annual Data Report: Atlas of chronic kidney disease \& end-stage renal disease in the United States. Am J Kidney Dis 59: e1-e420.

2. de Boer IH, Rue TC, Hall YN, Heagerty PJ, Weiss NS, et al. (2011) Temporal 
Citation: Velez MG, Bhalla V (2012) The Role of the Immune System in the Pathogenesis of Diabetic Nephropathy. J Nephrol Therapeutic S2. doi:10.4172/2161-0959.S2-007

Page 4 of 5

trends in the prevalence of diabetic kidney disease in the United States. JAMA 305: 2532-2539.

3. Ritz E, Orth SR (1999) Nephropathy in patients with type 2 diabetes mellitus. $N$ Engl J Med 341: 1127-1133.

4. Go AS, Chertow GM, Fan D, McCulloch CE, Hsu CY (2004) Chronic kidney disease and the risks of death, cardiovascular events, and hospitalization. N Engl J Med 351: 1296-1305.

5. Rossing P, Hougaard P, Borch-Johnsen K, Parving HH (1996) Predictors of mortality in insulin dependent diabetes: 10 year observational follow up study. BMJ 313: 779-784.

6. Perkins BA, Ficociello LH, Silva KH, Finkelstein DM, Warram JH, et al. (2003) Regression of microalbuminuria in type 1 diabetes. N Engl J Med 348: 22852293.

7. Nelson RG, Bennett PH, Beck GJ, Tan M, Knowler WC, et al. (1996) Development and progression of renal disease in Pima Indians with noninsulin-dependent diabetes mellitus. Diabetic Renal Disease Study Group. N Engl J Med 335: 1636-1642.

8. KDOQI (2007) KDOQI Clinical Practice Guidelines and Clinical Practice Recommendations for Diabetes and Chronic Kidney Disease. Am J Kidney Dis 49: S12-S154.

9. Fioretto P, Steffes MW, Sutherland DE, Mauer M (1995) Sequential renal biopsies in insulin-dependent diabetic patients: structural factors associated with clinical progression. Kidney Int 48: 1929-1935

10. Pagtalunan ME, Miller PL, Jumping-Eagle S, Nelson RG, Myers BD, et al. (1997) Podocyte loss and progressive glomerular injury in type II diabetes. J Clin Invest 99: 342-348

11. Kanwar YS, Akagi S, Sun L, Nayak B, Xie P, et al. (2005) Cell biology of diabetic kidney disease. Nephron Exp Nephrol 101: e100-e110.

12. Pambianco G, Costacou T, Ellis D, Becker DJ, Klein R, et al. (2006) The 30-year natural history of type 1 diabetes complications: the Pittsburgh Epidemiology of Diabetes Complications Study experience. Diabetes 55: 1463-1469.

13. Katsuki A, Sumida Y, Murashima S, Murata K, Takarada Y, et al. (1998) Serum levels of tumor necrosis factor-alpha are increased in obese patients with noninsulin-dependent diabetes mellitus. J Clin Endocrinol Metab 83: 859-862.

14. Yamagishi S, Inagaki Y, Okamoto T, Amano S, Koga K, et al. (2002) Advanced glycation end product-induced apoptosis and overexpression of vascular endothelial growth factor and monocyte chemoattractant protein-1 in humancultured mesangial cells. J Biol Chem 277: 20309-20315.

15. Wu CC, Chen JS, Lu KC, Chen CC, Lin SH, et al. (2010) Aberrant cytokines/ chemokines production correlate with proteinuria in patients with overt diabetic nephropathy. Clin Chim Acta 411: 700-704.

16. Mensah-Brown EP, Obineche EN, Galadari S, Chandranath E, et al. (2005) Streptozotocin-induced diabetic nephropathy in rats: the role of inflammatory cytokines. Cytokine 31: 180-190.

17. Wörnle M, Schmid H, Merkle M, Banas B (2004) Effects of chemokines on proliferation and apoptosis of human mesangial cells. BMC Nephrol 5: 8

18. Fornoni A, ljaz A, Tejada T, Lenz O (2008) Role of inflammation in diabetic nephropathy. Curr Diabetes Rev 4: 10-17.

19. Galkina E, Ley K (2006) Leukocyte recruitment and vascular injury in diabetic nephropathy. J Am Soc Nephrol 17: 368-377.

20. Ainsworth SK, Hirsch HZ, Brackett NC Jr, Brissie RM, Williams AV Jr, et al (1982) Diabetic glomerulonephropathy: histopathologic, immunofluorescent, and ultrastructural studies of 16 cases. Hum Pathol 13: 470-478.

21. Sassy-Prigent C, Heudes D, Mandet C, Bélair MF, Michel O, et al. (2000) Early glomerular macrophage recruitment in streptozotocin-induced diabetic rats. Diabetes 49: 466-475.

22. Nguyen D, Ping F, Mu W, Hill P, Atkins RC, et al. (2006) Macrophage accumulation in human progressive diabetic nephropathy. Nephrology (Carlton) 11: 226-231.

23. Chow F, Ozols E, Nikolic-Paterson DJ, Atkins RC, Tesch GH (2004) Macrophages in mouse type 2 diabetic nephropathy: correlation with diabetic state and progressive renal injury. Kidney Int 65: 116-128.
24. Chow FY, Nikolic-Paterson DJ, Atkins RC, Tesch GH (2004) Macrophages in streptozotocin-induced diabetic nephropathy: potential role in renal fibrosis. Nephrol Dial Transplant 19: 2987-2996.

25. Tesch GH (2007) Role of macrophages in complications of type 2 diabetes. Clin Exp Pharmacol Physiol 34: 1016-1019.

26. Zheng D, Wang Y, Cao Q, Lee VW, Zheng G, et al. (2011) Transfused macrophages ameliorate pancreatic and renal injury in murine diabetes mellitus. Nephron Exp Nephrol 118: e87- e99.

27. Chow FY, Nikolic-Paterson DJ, Ozols E, Atkins RC, Rollin BJ, et al. (2006) Monocyte chemoattractant protein-1 promotes the development of diabetic renal injury in streptozotocin-treated mice. Kidney Int 69: 73-80.

28. Chow FY, Nikolic-Paterson DJ, Ma FY, Ozols E, Rollins BJ, et al. (2007) Monocyte chemoattractant protein-1-induced tissue inflammation is critical fo the development of renal injury but not type 2 diabetes in obese $\mathrm{db} / \mathrm{db}$ mice. Diabetologia 50: 471-480.

29. Chow FY, Nikolic-Paterson DJ, Ozols E, Atkins RC, Tesch GH (2005) Intercellular adhesion molecule-1 deficiency is protective against nephropathy in type 2 diabetic db/db mice. J Am Soc Nephrol 16: 1711-1722.

30. Awad AS, Kinsey GR, Khutsishvili K, Gao T, Bolton WK, et al. (2011) Monocyte/ macrophage chemokine receptor CCR2 mediates diabetic renal injury. Am J Physiol Renal Physiol 301: F1358-F1366.

31. Bending JJ, Lobo-Yeo A, Vergani D, Viberti GC (1988) Proteinuria and activated T-lymphocytes in diabetic nephropathy. Diabetes 37: 507-511.

32. Moon JY, Jeong KH, Lee TW, Ihm CG, Lim SJ, et al. (2012) Aberrant Recruitment and Activation of T Cells in Diabetic Nephropathy. Am J Nephro 35: 164-174

33. Imani F, Horii Y, Suthanthiran M, Skolnik EY, Makita Z, et al. (1993) Advanced glycosylation endproduct-specific receptors on human and rat T-lymphocytes mediate synthesis of interferon gamma: role in tissue remodeling. J Exp Med 178: $2165-2172$

34. Eller K, Kirsch A, Wolf AM, Sopper S, Tagwerker A, et al. (2011) Potential role of regulatory $T$ cells in reversing obesity-linked insulin resistance and diabetic nephropathy. Diabetes 60: 2954-2962.

35. Lim AK, Ma FY, Nikolic-Paterson DJ, Kitching AR, Thomas MC, et al. (2010) Lymphocytes promote albuminuria, but not renal dysfunction or histological damage in a mouse model of diabetic renal injury. Diabetologia 53: 1772-1782.

36. Gurley SB, Clare SE, Snow KP, Hu A, Meyer TW, et al. (2006) Impact of genetic background on nephropathy in diabetic mice. Am J Physiol Renal Physiol 290 F214-F222.

37. Qi Z, Fujita H, Jin J, Davis LS, Wang Y, et al. (2005) Characterization of susceptibility of inbred mouse strains to diabetic nephropathy. Diabetes 54 2628-2637.

38. Awad AS, Rouse MD, Khutsishvili K, Huang L, Bolton WK, et al. (2011) Chronic sphingosine 1-phosphate 1 receptor activation attenuates early-stage diabetic nephropathy independent of lymphocytes. Kidney int 79: 1090-1098.

39. Østergaard J, Hansen TK, Thiel S, Flyvbjerg A (2005) Complement activation and diabetic vascular complications. Clin Chim Acta 361: 10-19.

40. Watanabe S, Tomino $\mathrm{Y}$, Inoue $\mathrm{W}$, Yagame $\mathrm{M}$, Kaneshige $\mathrm{H}$, et al. (1987) Detection of immunoglobulins and/or complement in kidney tissues from nonobese diabetic (NOD) mice. Tokai J Exp Clin Med 12: 201-208.

41. Atchley DH, Lopes-Virella MF, Zheng D, Kenny D, Virella G (2002) Oxidized LDL-anti-oxidized LDL immune complexes and diabetic nephropathy. Diabetologia 45: 1562-1571.

42. Nicoloff G, Blazhev A, Petrova C, Christova P (2004) Circulating immune complexes among diabetic children. Clin Dev Immunol 11: 61-66.

43. Di Mario U, Borsey DQ, Contreas G, Prowse CV, Clarke BF, et al. (1986) The relationship of soluble immune complexes, insulin antibodies and insulin-antiinsulin complexes to platelet and coagulation factors in type 1 diabetic patients with and without proliferative retinopathy. Clin Exp Immunol 65: 57-65.

44. Abrass CK (1984) Evaluation of the presence of circulating immune complexes and their relationship to glomerular $\operatorname{lgG}$ deposits in streptozotocin-induced diabetic rats. Clin Exp Immunol 57: 17-24.

45. Thiele GM, McDonald TL (1989) Assessment of the role of the immunoglobulin 
Citation: Velez MG, Bhalla V (2012) The Role of the Immune System in the Pathogenesis of Diabetic Nephropathy. J Nephrol Therapeutic S2. doi:10.4172/2161-0959.S2-007

isotypes in the development of diabetic nephropathy in untreated streptozotocin induced diabetic rats. Diabetes Res 12: 15-24.

46. Xiao X, Ma B, Dong B, Zhao P, Tai N, et al. (2009) Cellular and humoral immune responses in the early stages of diabetic nephropathy in NOD mice. $J$ Autoimmun 32: 85-93.

47. Fujita T, Ohi H, Komatsu K, Endo M, Ohsawa I, et al. (1999) Complement activation accelerates glomerular injury in diabetic rats. Nephron 81: 208-214.

48. Abdelsamie SA, Li Y, Huang Y, Lee MH, Klein RL, et al. (2011) Oxidized LDL immune complexes stimulate collagen IV production in mesangial cells via Fc gamma receptors I and III. Clin Immunol 139: 258-266.

49. Saad AF, Virella G, Chassereau C, Boackle RJ, Lopes-Virella MF (2006) OxLDL immune complexes activate complement and induce cytokine production by MonoMac 6 cells and human macrophages. J Lipid Res 47: 1975-1983.

50. Nicoloff G, Baydanoff S, Petrova Ch, Christova P (2002) Antibodies to advanced glycation end products in children with diabetes mellitus. Vascul Pharmacol 39: 39-45.

51. Mustafa I, Ahmad S, Dixit K, Moinuddin, Ahmad J, et al. (2012) Glycated human DNA is a preferred antigen for anti-DNA antibodies in diabetic patients. Diabetes Res Clin Pract 95: 98-104.

52. Khan MW, Banga K, Mashal SN, Khan WA (2011) Detection of autoantibodies against reactive oxygen species modified glutamic acid decarboxylase-65 in type 1 diabetes associated complications. BMC Immunol 12: 19.

53. Fredrikson GN, Anand DV, Hopkins D, Corder R, Alm R, et al. (2009) Associations between autoantibodies against apolipoprotein B-100 peptides and vascular complications in patients with type 2 diabetes. Diabetologia 52: 1426-1433.
54. Palmer JP, Asplin CM, Clemons P, Lyen K, Tatpati O, et al. (1983) Insulin antibodies in insulin-dependent diabetics before insulin treatment. Science 222: $1337-1339$

55. Giardina E, Triolo G, Accardo-Palumbo A, Carbone MC, Gancitano V, et al (1997) Anti-single-stranded DNA antibody in the sera of patients with type 2 diabetes mellitus. Relation to vascular complications. Acta Diabetol 34: 39-41.

56. Lopes-Virella MF, Virella G, Orchard TJ, Koskinen S, Evans RW, et al. (1999) Antibodies to oxidized LDL and LDL-containing immune complexes as risk factors for coronary artery disease in diabetes mellitus. Clin Immunol 90: 165172.

57. Virella G, Carter RE, Saad A, Crosswell EG, Game BA, et al. (2008) Distribution of $\operatorname{lgM}$ and $\lg$ antibodies to oxidized LDL in immune complexes isolated from patients with type 1 diabetes and its relationship with nephropathy. Clin Immunol 127: 394-400

58. Palinski W, Miller E, Witztum JL (1995) Immunization of low density lipoprotein $(\mathrm{LDL})$ receptor-deficient rabbits with homologous malondialdehyde-modified LDL reduces atherogenesis. Proc Natl Acad Sci U S A 92: 821-825.

59. Utimura R, Fujihara CK, Mattar AL, Malheiros DM, Noronha IL, et al. (2003) Mycophenolate mofetil prevents the development of glomerular injury in experimental diabetes. Kidney int 63: 209-216.

60. Moriwaki Y, Inokuchi T, Yamamoto A, Ka T, Tsutsumi Z, et al. (2007) Effect of TNF-alpha inhibition on urinary albumin excretion in experimental diabetic rats Acta Diabetol 44: 215-218.

61. Cheung AK, Greenberg A, National Kidney Foundation (2009) Primer on kidney diseases. (5thedn), Saunders/Elsevier National Kidney Foundation, Philadelphia, PA. 